\title{
Molecular evidence of Rickettsia raoultii, "Candidatus Rickettsia barbariae" and a novel Babesia genotype in marbled polecats (Vormela peregusna) at the China- Kazakhstan border
}

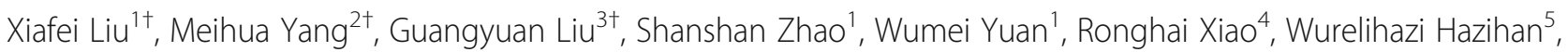 \\ Sándor Hornok ${ }^{6}$ and Yuanzhi Wang ${ }^{*}$
}

\begin{abstract}
In this study, two road-killed marbled polecats (Vormela peregusna) were molecularly analysed for tick-borne pathogens. Rickettsia raoultii, "Candidatus Rickettsia barbariae" and a novel Babesia genotype have been identified, for the first time in marbled polecat. DNA of this Babesia sp. genotype was also present in four out of 15 Haemaphysalis erinacei ticks collected from the Babesia PCR-positive marbled polecat. Results of this study suggest that marbled polecats may serve as reservoirs for these bacteria and protozoans.
\end{abstract}

Keywords: Babesia, "Candidatus Rickettsia barbariae", China-Kazakhstan border, Haemaphysalis erinacei, Marbled polecat, Rickettsia raoultii

\section{Letter to the Editor}

The marbled polecat (Vormela peregusna) is a small carnivorous mammal (Carnivora: Mustelidae) with a broad geographical range, extending from southeast Europe, through southwest and central Asia, to Mongolia and northern China. This species is the only member of the genus and has been listed as globally vulnerable, due to substantially declining populations [1]. Apart from the loss of steppe habitats and desertification, infection with various pathogens may contribute to its decreasing numbers. At the same time, data are very limited on the epidemiological role of the marbled polecat as a reservoir of pathogens with veterinary or medical significance [2, 3]. Therefore, molecular investigations for pathogens in this endangered species have multifold importance.

\footnotetext{
*Correspondence: wangyuanzhi621@126.com

'Xiafei Liu, Meihua Yang and Guangyuan Liu contributed equally to this work.

'School of Medicine, Shihezi University, Shihezi, Xinjiang Uygur Autonomous Region 832002, People's Republic of China

Full list of author information is available at the end of the article
}

In May and June 2014, two road-killed, female marbled polecats, were found around wetlands of Ebinur Lake (189 m above sea level; coordinates: $82^{\circ} 48^{\prime} 51^{\prime \prime} \mathrm{E}, 45^{\circ} 04^{\prime} 22^{\prime \prime N}$ ) in northwestern China, in the border region near Kazakhstan. Previously, 21 Haemaphysalis erinacei ticks collected from the two animals (15 from polecat \#1 and six from polecat \#2) were molecularly characterised at $16 \mathrm{~S}$ mitochondrial gene region. Two of 15 ticks (13.33\%) collected from marbled polecat \#1 were infected with Rickettsia raoultii [4]. The two animals were brought to the Xinjiang Uygur Autonomous Region Wildlife Management Office and then sent to the Laboratory of High Incidence of Local and Ethnic Diseases in Xinjiang for necropsy analyses. DNA extractions from the liver and spleen were carried out using the TIANamp Genomic DNA Kit (TIANGEN, Beijing, China). The presence of DNA from tick-borne pathogens was investigated by PCR amplification and sequencing of parts of the following genes: the 17-kDa surface antigen gene (17 kDa gene) of Rickettsia spp., the 5S-23S rRNA gene of Borrelia spp., the $16 S$ rRNA gene of Anaplasmataceae, and the $18 S$ rRNA gene of Babesia spp., as described previously [5-7]. All samples were negative 
for Borrelia spp. and Anaplasmataceae. To confirm the results and to compare additional genetic markers, further PCR and sequencing were performed, to detect the outer membrane protein $\mathrm{A}($ ompA) and cell surface antigen 1 (sca1) genes of Rickettsia spp. [5] and the cytochrome $b$ $(c y t b)$ gene of Babesia spp. [8]. All PCRs were performed including double distilled water $\left(\mathrm{ddH}_{2} \mathrm{O}\right)$ as a negative control. Sequences were compared with GenBank data using the nucleotide BLAST program (http://www.ncbi.nlm.nih. gov/BLAST/). All obtained sequences were deposited in the GenBank database [17-kDa: MG674917 ( $R$. raoultii) and MG674918 ("Candidatus Rickettsia barbariae"); ompA: MG662380 ( $R$. raoultii) and MG662381 ("Candidatus Rickettsia barbariae"); sca1: MG662382 (R. raoultii) and MG662383 ("Candidatus Rickettsia barbariae"); $18 S$ rRNA: MG799848 and MG813565; cytb: MG832590 and MG832591 (Babesia sp. from marbled polecat and H. erinacei, respectively)].
However, the liver and spleen samples of both marbled polecats were PCR-positive for rickettsiae. In animal \#1, the ompA and scal sequences showed 100\% identities with $R$. raoultii strain Khabarovsk ${ }^{\mathrm{T}}$ (GenBank: CP010969). This result is in line with previous findings, i.e. two out of the fifteen ticks (i.e. 13.33\%) collected from animal \#1 harboured $R$. raoultii. The phylogenetic analysis showed that the genetic pattern was the same between $R$. raoultii from a marbled polecat \#1 and $R$. raoultii previously found in $H$. erinacei ticks collected from marbled polecat \#1 (Fig. 1) [4]. In animal \#2, "Candidatus Rickettsia barbariae" was identified, with 99.8\% (552/553 bp) and 100\% (443/443 bp) similarities to sequences available in GenBank [from Vermipsylla alakurt in China: KT284718 (sca1) and KU645284 (ompA)]. Results of sequence alignments were confirmed by phylogenetic analyses, placing rickettsiae detected here into the cluster of either R. raoultii or "Candidatus Rickettsia barbariae" (Fig. 1 and Additional file 1: Table S1).

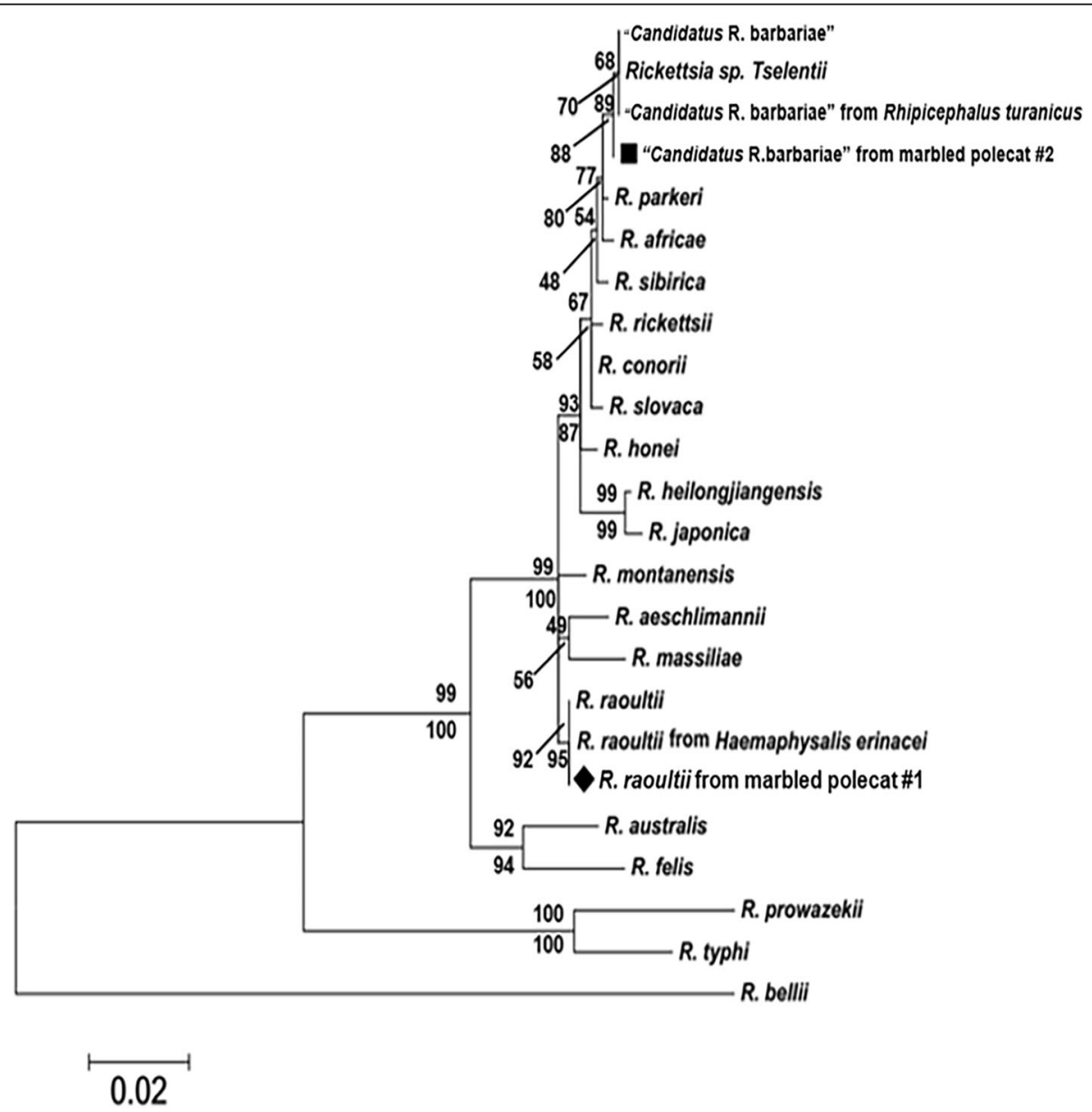

Fig. 1 Phylogenetic tree of the 17-kDa (393 bp) - ompA (443 bp) - scal (553 bp) concatenated sequences for "Candidatus Rickettsia barbariae" (indicated by a square) and $R$. raoultii (indicated by a diamond) from the marbled polecat obtained in this study, and sequences for Rickettsia species retrieved from the GenBank database. The tree was constructed using the neighbour-joining method (NJ; 1000 bootstrap replicates) and maximum-likelihood (ML; 1000 bootstrap replicates) analyses using MEGA6. The scale-bar represents the inferred substitutions per nucleotide site. The relative support for clades in the tree was produced from the NJ and $\mathrm{ML}$ analyses 
Both Rickettsia spp. were detected for the first time in marbled polecats. Spotted fever group rickettsiae (Proteobacteria: Rickettsiales) are obligatory intracellular, Gram-negative bacteria, which can cause zoonotic disease after transmission by a blood-sucking arthropod [9]. Rickettsia raoultii is one of the causative agents of human rickettsioses (SENLAT/TIBOLA/DEBONEL [10]). Until recently, $R$. raoultii has not been reported from mammals other than humans [11], but during the past years, this species was detected in Mongolian gazelle [12] and dogs [13]. The most important tick vectors of $R$. raoultii appear to be Dermacentor spp., with transstadial and transovarial maintenance of this agent [14]. Accordingly, a previous study revealed $R$. raoultii as the predominant species of Rickettsia found in D. nuttalli from Mongolian regions and in D. silvarum ticks in the border region between China and Russia $[15,16]$. Therefore, simultaneous detection of $R$. raoultii in a marbled polecat (as shown here) and in $H$. erinacei removed from the same animal justify further studies on the vector role of this tick species, which is outside the typical vector range of $R$. raoultii.

"Candidatus Rickettsia barbariae" has been detected and described from ticks of domestic and wild animals [17-20] and humans [21] in the Mediterranean region. Our previous work also showed the presence of DNA of "Candidatus Rickettsia barbariae" in the tick Rhipicephalus turanicus [22] and the flea Vermipsylla alakurt [5] collected from sheep around the Taklamakan Desert in Xinjiang, northwestern China. To the best of our knowledge, "Candidatus Rickettsia barbariae" was not detected in any vertebrate hosts of the above ectoparasites, further increasing the significance of the present findings.

In addition to the above results, Babesia sp. DNA was detected both in four H. erinacei ticks and the organs of

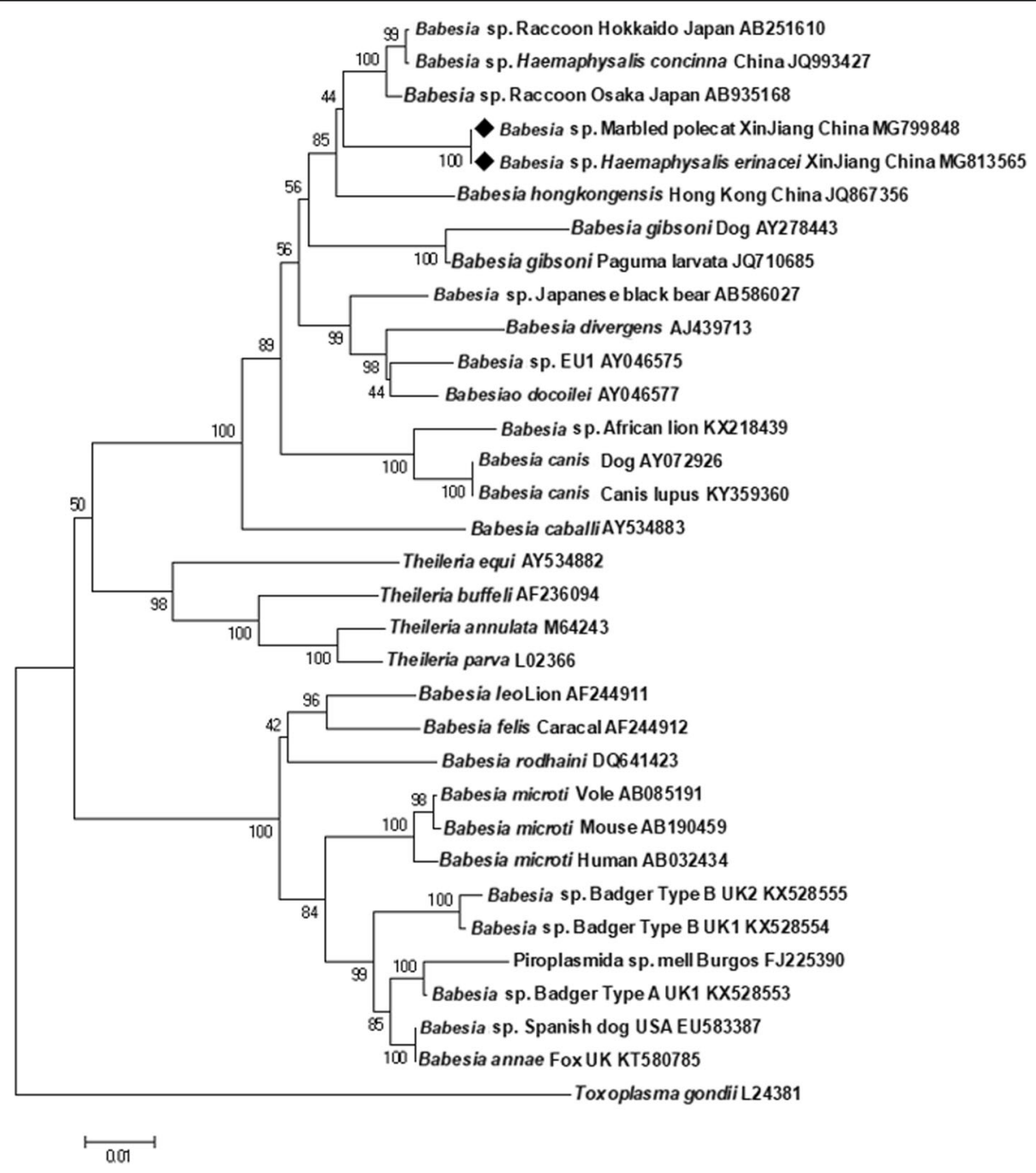

Fig. 2 Phylogenetic comparison of 1601 bp $18 \mathrm{~S}$ rRNA gene sequence of Babesia sp. from the marbled polecat and Babesia sp. Haemaphysalis erinacei identified in the present study (diamonds) and relevant sequences from the GenBank database. The results are based on the neighbour-joining ( $N$ j; 1000 bootstrap replicates) approximation of the standard likelihood ratio test score. The scale-bar indicates the base pair substitution rate 
their parasitised host (marbled polecat \#1). The $18 \mathrm{~S}$ rRNA gene sequences were $100 \%$ identical between the marbled polecat and its PCR-positive ticks. However, this Babesia genotype had only $97.12 \%$ (1517/1562 bp) $18 S$ rRNA gene similarity to the closest genotype in GenBank, detected in the blood of a racoon in Japan (GenBank: AB935168). The cytb gene sequence comparisons supported the uniqueness of this Babesia sp. from marbled polecat because the gene sequence showed $85.74 \%$ (433/505 bp) similarity to that of Babesia gibsoni (no corresponding cytb gene sequence was found for Babesia sp. from a racoon in GenBank). The phylogenetic analysis confirmed these results: this novel Babesia genotype clustered separately from the above racoon-associated piroplasm (GenBank: AB935168) and belonged to a phylogenetic group including Babesia spp. from Caniformia or tick species (i.e. $H$. concinna and from the present study $H$. erinacei) frequently infesting Caniformia (Fig. 2). The separation of this phylogenetic group from a cat-associated piroplasm (B. hongkongensis) was strongly (85\%) supported (Fig. 2).

To the best of our knowledge, this is the first report on the presence of Babesia DNA in marbled polecat and $H$. erinacei ticks. Babesia spp. (Apicomplexa: Piroplasmida) are intraerythrocytic parasites, which have been reported from birds and mammals (including wild carnivores) worldwide $[7,23]$ and have ixodid ticks as their principal vectors [24]. The $18 \mathrm{~S}$ rRNA gene is the most widely used genetic marker for the identification of babesiae [24]. Based on $18 \mathrm{~S}$ rRNA gene sequence data and the topology of the phylogenetic tree (Fig. 2), the Babesia sp. detected here in the marbled polecat, and the attendant ticks was most closely related to a Babesia sp. from a racoon (GenBank: AB935168: reported from Osaka, Japan) and differed from all other piroplasmid species. Taking into account that the $18 S$ rRNA gene may have very few nucleotide substitutions between closely related species [e.g. only $0.2 \%$ difference delineating $B$. divergens (GenBank: FJ944825) and B. capreoli (GenBank: AY726009) [25]], this new Babesia genotype most likely represents a species different from the one detected in raccoon in Japan. Unfortunately, morphological characterisation of this novel Babesia genotype was not possible because samples were obtained from road-killed (i.e. not freshly dead) animals, and Babesia are known to undergo quick degradation and morphological changes post-mortem [26].

In conclusion, results of this study suggest that marbled polecats may serve as reservoirs for R. raoultii, "Candidatus Rickettsia barbariae" and a novel Babesia genotype. Further studies are needed to evaluate if rickettsemia in this host species is of sufficient magnitude and duration to infect ticks, which is a known prerequisite for effective transmission of other tick-borne rickettsiae [27].

\section{Additional file}

Additional file 1: Table S1. Information for the sequences from the GenBank database used in Fig. 1. (DOCX 18 kb)

\begin{abstract}
Abbreviations
cytb: cytochrome b; DEBONEL: Dermacentor-borne necrosis, eschar and lymphadenopathy; HGA: human granulocytic anaplasmosis; IUCN: International Union for Conservation of Nature; ompA: outer membrane protein A; sca1: surface cell antigen 1; TIBOLA: tick-borne lymphadenopathy
\end{abstract}

\section{Acknowledgements}

The authors thank the contributions by the staff at the School of Medicine, Shihezi University.

\section{Funding}

This research was supported in part by the National Key Research \& Development Program of China (2018ZX10101002, 2017YFD0500304 and 2016YFC1202002), National Natural Science Foundation of China (81560338 and U1503283), State Key Laboratory of Veterinary Etiological Biology (SKLVEB2017KEKT009), and International Scientific and Technological Cooperation in Bingtuan (2016AH001).

\section{Availability of data and materials}

The sequences obtained and analysed during the present study are deposited in the GenBank database, under the accession numbers MG674917, MG662380 and MG662382 (R. raoultii); MG674918, MG662381 and MG662383 ("Candidatus Rickettsia barbariae"); MG799848, MG813565, MG832590 and MG832591

(Babesia sp.). All other relevant data are included in the article.

\section{Authors' contributions}

$X L, M Y, G L$ and YW conceived and designed the study. SZ, WY, RX and WH processed the samples and performed molecular and phylogenetic analyses. $\mathrm{SH}$ contributed to the study design and the manuscript. All authors read and approved the final manuscript.

\section{Ethics approval}

This study was approved by the Animal Ethics Committee of Shihezi University (Approval No. AECSU2014-03).

Consent for publication

Not applicable.

\section{Competing interests}

The authors declare that they have no competing interests.

\section{Publisher's Note}

Springer Nature remains neutral with regard to jurisdictional claims in published maps and institutional affiliations.

\section{Author details}

${ }^{1}$ School of Medicine, Shihezi University, Shihezi, Xinjiang Uygur Autonomous Region 832002, People's Republic of China. ${ }^{2}$ School of Agriculture, Shihezi University, Shihezi, Xinjiang Uygur Autonomous Region 832000, People's Republic of China. ${ }^{3}$ State Key Laboratory of Veterinary Etiological Biology, Key Laboratory of Veterinary Parasitology of Gansu Province, Lanzhou Veterinary Research Institute, Chinese Academy of Agricultural Science, Xujiaping 1\#, Lanzhou, Gansu 730046, People's Republic of China. ${ }^{4}$ Inspection and Comprehensive Technology Center of Ruili Entry-Exit Inspection and Quarantine Bureau, No.75, Ruihong Road, Ruili 678600, Yunnan, People's Republic of China. ${ }^{5}$ School of Animal Science and Technology, Shihezi University, Shihezi, Xinjiang Uygur Autonomous Region 832000, People's Republic of China. ${ }^{6}$ Department of Parasitology and Zoology, University of Veterinary Medicine, Budapest, Hungary. 
Received: 28 April 2018 Accepted: 24 July 2018

Published online: 04 August 2018

\section{References}

1. International Union for Conservation of Nature (IUCN). IUCN Red List of Threatened Species, 2008. http://www.iucnredlist.org/. Accessed 25 Apr 2018

2. Faizulin FG. Cutaneous leishmaniasis in a mottled polecat (Vormela peregusna Cueld). Med Parazitol. 1967;36:494-5.

3. Gherman CM, Sándor AD, Kalmár Z, Marinov M, Mihalca AD. First report of Borrelia burgdorferi sensu lato in two threatened carnivores: the marbled polecat, Vormela peregusna and the European mink, Mustela lutreola (Mammalia: Mustelidae). BMC Vet Res. 2012:8:137.

4. Guo LP, Mu LM, Xu J, Jiang SH, Wang AD, Chen CF, et al. Rickettsia raoultii in Haemaphysalis erinacei from marbled polecats, China-Kazakhstan border. Parasit Vectors. 2015;8:461.

5. Zhao SS, Li HY, Yin XP, Liu ZQ, Chen CF, Wang YZ. First detection of Candidatus Rickettsia barbariae in the flea Vermipsylla alakurt from northwestern China. Parasit Vectors. 2016;9:325.

6. Wielinga PR, Gaasenbeek C, Fonville M, Boer DA, Vries DA, Dimmers W, et al. Longitudinal analysis of tick densities and Borrelia, Anaplasma, and Ehrlichia infections of Ixodes ricinus ticks in different habitat areas in The Netherlands. Appl Environ Microbiol. 2006;72:7594-601.

7. Bartley PM, Wilson C, Innes EA, Katzer F. Detection of Babesia DNA in blood and spleen samples from Eurasian badgers (Meles meles) in Scotland. Parasitology. 2017;144:1203-10.

8. Tian Z, Luo J, Zheng J, Xie J, Shen $\mathrm{H}$, Yin H, et al. Phylogenetic analysis of Babesia species in China based on cytochrome b (COB) gene. Infect Genet Evol. 2013:13:36-40.

9. Parola P, Paddock CD, Socolovschi C, Labruna MB, Mediannikov O, Kernif T, et al. Update on tick-borne rickettsioses around the world: a geographic approach. Clin Microbiol Rev. 2013;26:657-702.

10. Parola P, Rovery C, Rolain JM, Brouqui P, Davoust B, Raoult D. Rickettsia slovaca and $R$. raoultii in tick-borne rickettsioses. Emerg Infect Dis. 2009;15: 1105-8.

11. Karbowiak G, Biernat B, Stańczak J, Szewczyk T, Werszko J. The role of particular tick developmental stages in the circulation of tick-borne pathogens affecting humans in central Europe. 3. Rickettsiae. Ann Parasitol. 2016;62:89-100.

12. Li Y, Chen Z, Liu Z, Liu J, Yang J, Li Q, et al. First report of Theileria and Anaplasma in the Mongolian gazelle, Procapra gutturosa. Parasit Vectors. 2014;7:614.

13. Liesner JM, Krücken J, Schaper R, Pachnicke S, Kohn B, Müller E, et al. Vector-borne pathogens in dogs and red foxes from the federal state of Brandenburg, Germany. Vet Parasitol. 2016;224:44-51.

14. Mediannikov O, Matsumoto K, Samoylenko I, Drancourt M, Roux V, Rydkina E, et al. Rickettsia raoultii sp. nov., a spotted fever group rickettsia associated with Dermacentor ticks in Europe and Russia. Int J Syst Evol Microbiol. 2008;58:1635-9.

15. Speck S, Derschum H, Damdindorj T, Dashdavaa O, Jiang J, Kaysser P, et al. Rickettsia raoultii, the predominant rickettsia found in Mongolian Dermacentor nuttalli. Ticks Tick Borne Dis. 2012;3:227-31.

16. Wen J, Jiao D, Wang JH, Yao DH, Liu ZX, Zhao G, et al. Rickettsia raoultii, the predominant rickettsia found in Dermacentor silvarum ticks in China-Russia border areas. Exp Appl Acarol. 2014;63:579-85.

17. Sousa RD, Barata C, Vitorino L, Santos-Silva M, Carrapato C, Torgal J, et al. Rickettsia sibirica isolation from a patient and detection in ticks, Portugal. Emerg Infect Dis. 2006;12:1103-8.

18. Mura A, Masala G, Tola S, Satta G, Fois F, Piras P, et al. First direct detection of rickettsial pathogens and a new rickettsia, "Candidatus Rickettsia barbariae", in ticks from Sardinia, Italy. Clin Microbiol Infect. 2008;14:1028-33.

19. Chochlakis D, loannou I, Sandalakis V, Dimitriou T, Kassinis N, Papadopoulos $B$, et al. Spotted fever group rickettsiae in ticks in Cyprus. Microb Ecol. 2012;63:314-23.

20. Pereira A, Parreira R, Cotão AJ, Nunes M, Vieira ML, Azevedo F, et al. Tickborne bacteria and protozoa detected in ticks collected from domestic animals and wildlife in central and southern Portugal. Ticks Tick Borne Dis. 2018:9:225-34

21. Papa A, Xanthopoulou K, Kotriotsiou T, Papaioakim M, Sotiraki S, Chaligiannis I, et al. Rickettsia species in human-parasitising ticks in Greece. Trans R Soc Trop Med Hyg. 2016;110:299-304.
22. Guo LP, Jiang SH, Liu D, Wang SW, Chen CF, Wang YZ. Emerging spotted fever group rickettsiae in ticks, northwestern China. Ticks Tick Borne Dis. 2016;7:1146-50.

23. Kawabuchi T, Tsuji M, Sado A, Matoba Y, Asakawa M, Ishihara C. Babesia microti-like parasites detected in feral racoons (Procyon lotor) captured in Hokkaido, Japan. J Vet Med Sci. 2005;67:825-7.

24. Hunfeld KP, Hildebrandt A, Gray JS. Babesiosis: recent insights into an ancient disease. Int J Parasitol. 2008;38:1219-37.

25. Malandrin L, Jouglin M, Sun Y, Brisseau N, Chauvin A. Redescription of Babesia capreoli (Enigk and Friedhoff, 1962) from roe deer (Capreolus capreolus): isolation, cultivation, host specificity, molecular characterisation and differentiation from Babesia divergens. Int J Parasitol. 2010;40:277-84.

26. Demeter Z, Palade EA, Balogh E, Jakab C, Farkas R, Tánczos B, et al. Postmortem small Babesia-like morphology of Babesia canis. Acta Vet Hung. 2011:59:427-32.

27. Telford SR, Parola P. Arthropods and Rickettsiae. In: Parola P, Raoult D, editors. Rickettsial diseases, Infectious diseases and therapy collection. New York: Informa Healthcare; 2007.
Ready to submit your research? Choose BMC and benefit from:

- fast, convenient online submission

- thorough peer review by experienced researchers in your field

- rapid publication on acceptance

- support for research data, including large and complex data types

- gold Open Access which fosters wider collaboration and increased citations

- maximum visibility for your research: over $100 \mathrm{M}$ website views per year

At $\mathrm{BMC}$, research is always in progress.

Learn more biomedcentral.com/submissions 